\title{
原著 体表面電位図上のQ波による左室前壁収縮異常の診断
}

\section{標準12誘導心電図に梗塞所見の見られない冠動脈疾患を対象として}

\author{
名古屋大学医学部第一内科（主任 蔳藤英彦教授） \\ 矢部誠太郎 $\diamond$ 林 博史 石川富久 宮地恭一 大杉茂樹 高見和秀 外畑 厳
}

\begin{abstract}
概要＼cjkstart標準12誘遷心電図による心筋梗塞の診断が困難であるが，心血管造影にて，左室前壁に 限局する収縮異常を示した冠動脈疾患患者48名（疾患群）を対象とし，体表面電位图を記録し， 各誘導点のQ $\mathbf{Q}_{30}(\mathrm{Q}$ 波 $\geqq 30 \mathrm{msec}$ ）の出現率を健常群57名のそれと比較した. 疾患群ではV1・V2 誘導点の上方領域およU゙右胸部で $\mathbf{Q}_{30}$ の出現率が有意に高かつた。， $\mathbf{Q}_{30}$ による感度は17〜 56\%で あつたが, 陽性予測率は63〜92\%と高かつた. 収縮異常高度群は軽度群に比へ，同様の領域で $\mathbf{Q}_{30}$ の出現率が高かった。:ニれらの結果から，標準12誘導心電图誘道にV1・V2誘導点の上方領 域およひ右胸部の誘導を加えることにより前壁収縮異常の心電图診断の精度が向上すると考え られた.

[日内会誌 $75 ： 375 \sim 381 ， 1981$ ]
\end{abstract}

\section{緒 言}

標準12誘導心電図での異常 $\mathrm{Q}$ 波，または胸部誘 導に拉ける poor $\mathrm{r}$ wave progressionは心筋梗塞 の診断，または左室壁収縮異常の推定に重要な所 見としてその臨床的価値は高い12) しかし，壁収 縮異常の存在にもかかわらず標準12誘導心電図に 異常Q波，またはpoor $\mathrm{r}$ wave progressionを認め ないことも必ずしも少なくない，この理由の一つ として，標準12誘導心電図では胸壁上の誘導点数 が 6 点と限定されているため，心筇梗塞，あるい は心筋虚血を示唆する電気情報が表現されないこ とが考えられる ${ }^{344)}$.これまでに, poor $\mathrm{r}$ wave progressionを示す症例の中での心筇梗塞と他の 左室肥大，右室肥大等との鑑別に適当な電位基準 の検討5)や，標準12誘導心電図に心筋梗塞所見が ないにもかかわらず、V1〜V6以外の単極胸部誘 導で心筇梗塞猃断が可能であつた症例の報告は散 見されるが(6)7，標準12誘導心電図で心筋梗塞の診 断が不能であつた症例の標準誘導点以外の領域に
扣ける異常Q波の出現率についての詳細かつ系統 的な観察はほとんどみられない。

本研究は，左前下行枝病変を伴 左室前壁収縮 異常を有するが, 標準12誘導心電図上, 異常Q波に 基づく従来の診断基準からはその判定が困難であ つた例について，左室前壁収縮異常の有無を判定 するために有用な標準胸部誘導以外の誘導を検索 することを目的とした。

\section{対象・方法}

対象は標準12誘導心電図，および心血管造影所 見にもとついた以下の選択基準全てを満たした冠 動脈疾患患者48名であり，これを疾患群とした。

1) 冠動脈造影上,少なくとも左前下行枝に内径 $75 \%$ 以上の狭窄を有し，左室造影上，前壁または 前壁中隔にのみ収縮異常が存在する。

2）標準12誘導心電図上，III执よびaVR以外の 誘導で30 msec以上の幅を有するQ波 $\left(\mathrm{Q}_{30}\right)$ を認め ないかまたは胸部誘導において poor $r$ wave progression"

〔昭和60年 6 月24日受稿〕本論文の一部は第47回日本循環器学会総会（昭和58年 4 月 3 日）に拈いて発表した。

Diagnostic value of the $Q$ wave in body surface potential map for estimation of left anterior wall asynergy in patients with coronary artery disease without abnormal $Q$ wave on standard 12-lead electrocardiogram.

Seitaro Yabe, Hiroshi Hayashi, Tomihisa Ishikawa, Kyoichi Miyachi, Shigeki Ohsugi, Kazuhide Takamı and Iwao SoтоватA, The First Department of Internal Medicine, Nagoya University, School of Medicine, Nagoya (Director: Prof. Hidehiko Saito ) 
progression" ${ }^{5}$ が認められない，ただし，I交たは aVLのどちらか一方にのみ到を示す症例は正常 でもありらる8とされているため対象に含めた。 弁膜症, 心奇型, 心筋症, 胸郭形成術施行などに よる胸郭変形および肺気腫を有する患者は除外し た。をた，前額面QRS平均電気軸がー30度を越え る左軸偏位または+110度以上の右軸偏位を示す 患者は対象から除外した。

1)の条件を満たした前壁収縮異常例は145例で あり，このうち97例（67\%）が標準12誘導心電図 で異常Q波，あるいはpoor $\mathrm{r}$ wave progressionk より心筫梗塞との診断が可能であつたので, 残り の48例（32\%）を対象とした，対象は全例男性で あり, 年令は 40 才から68才, 平均53.6土7.0才であ つた。典型的な臨床症状, 標準12誘導心電図変化 および血清酵素学的変化により診断された急性心 筋梗塞の既往を有する患者 (心筋梗塞群) は48例 中15例（31\%）であり，その他の33例（69\%）は 急性心筋梗塞の既往のない労作狭心症患者（狭心 症群）であつた。

左室壁収縮状態は左右両斜位左室造影像にて評 価し, dyskinesis叔よびakinesisを高度収縮異常, hypokinesisを軽度収縮異常とした。疾患群におけ るそれぞれの頻度は高度収縮異常群が11例 (23\%)，軽度收縮異常群が37例（77\%）であつた。 また，心筋梗塞群の中では，前者は 3 例（20\%）, 後者は 12 例 $(80 \%)$ であり，狭心症群に括いては おの㧍の，8例（24\%）技よび25例（76\%）であ つた.

対照群として，明らかな心血管系疾患のない健 常成人男子 57 名（平均年令 $33.5 \pm 11.4$ 才）を用い た。

体表面電位図はHPM-5100(中日電子社製)を用 いて, Wilson中心電位を基準として, 胸部および 背部の85誘導点（図 1)より同時記録した単極誘 導心電図をもとに作製した9)。 $\mathrm{T}$ 一P線にて基線補 正し，同時に記録したFrank法空間マグニチュー ド心電図および空間速度心電図からQRS開始点 を決定した。

疾患群と対照群それぞれについて各誘導点毎に
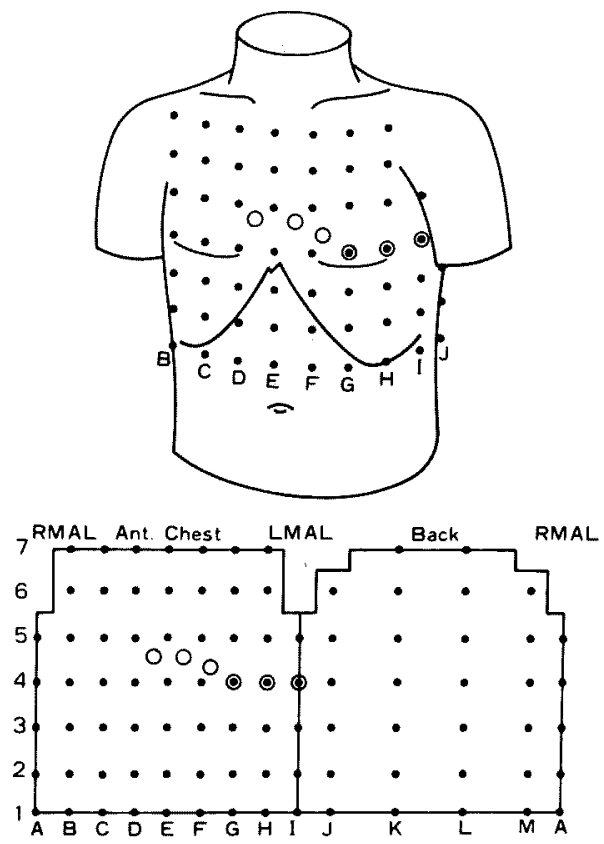

図 1. 電極配置図

上段はtorso上の電極配置を，下段はその展開図を示

す.図中の6つの白丸は標準胸部誘導点を示す。

Ant. chest $=$ 胸部, $B a c k=$ 背部, $\mathrm{RMAL}=$ 右中腋窝

線, $\mathrm{LMAL}=$ 左中腋窝線

$\mathrm{Q}_{30}$ の出現率を求め, 両群間にお゙ける $\mathrm{Q}_{30}$ の出現率 の差を直接確率計算法を用いて検定した。次いで 心筋梗塞群と狭心症群別, 扣よび収縮異常の程度 別にQ $\mathrm{Q}_{30}$ の出現率を対照群のそれと比較した。ささら に心筋梗塞群と㹟心症群間で $\mathrm{Q}_{30}$ の出現頻度を比 較した。“ “ $\mathrm{Q}_{30}$ の存在”を収縮異常の診断基準として 以下の式に従い各群に拈ける感度, 特異度, 陽性 予测率, 陰性予測率扣よび診断精度を求めた。

感度 $(\%)=($ 真陽性 $/($ 真陽性十偽陰性 $)) \times 100$ ： 疾患群に括ける $\mathrm{Q}_{30}$ 陽性率

特異度 $(\%)=($ 真陰性 $/($ 真陰性十偽陽性) ) $\times$ 100：対照群に括けるQ 30 陰性率

陽性予測率 (\%) =(真陽性/(真陽性十為陽 性)) $\times 100 ： \mathrm{Q}_{30}$ 陽性例中の疾患群の頻度

陰性予測率 (\%) $=$ (真陰性/(真陰性十偽陰 性)) $\times 100 ： Q_{30}$ 陰性例中の対照群の頻度

診断精度 $(\%)=(($ 真陽性 + 真陰性 $) /$ 全症例 $) \times$ 100：正診率 


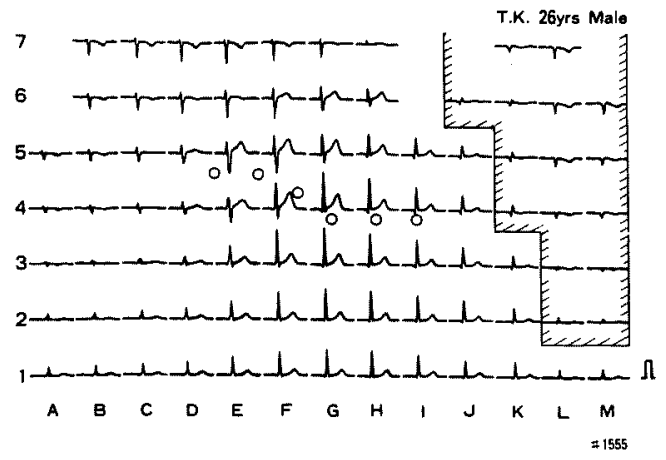

図 2。対照群の 1 例

図中, 斜線で囲つた領域は $\mathrm{Q}_{30}$ (幅 $30 \mathrm{msec}$ 以のQ 波）の出現領域を示す。をた，6つの白丸は標準胸部 誘導点を示す．右下段の校正波は $1 \mathrm{mV}$ の大きさ示 す。

右背部上方を中心に $\mathrm{Q}_{30}$ が出現している（M列 2 $\sim 6$, L列 $2 \sim 7, \mathrm{~K}$ 列 $4 \sim 7$, J列 6 ).

次に，前壁収縮異常を推定する5党で有用な誘 導点を抽出するために，陽性予測率が高く，かつ 感度も高い 2 誘導点を選択し，どちらかの誘導点 にQ ${ }_{30}$ が出現すればQ $Q_{30}$ 陽性とした場合の上記諸診 断率を求めた。同様にして 3 および 4 誘導点を選 択した場合についてb検討した。

\section{結果}

\section{対照群における $\mathbf{Q}_{\mathbf{3 0}}$ 出現率の体表面分布}

図 2 は対照群の 1 例であるが，Q 中心に出現L（M列 $2 \sim 6$, L列 $2 \sim 7$, K列 4 ～7, J列 6)，胸部和よび背部中央から下方にか けては出現しなかつた。

対照群全体に和いては図 3 の上うに, $\mathrm{Q}_{30}$ の出現 率が90\%以上の領域は右背部括よび背部中央上方 (M列 $4 \sim 5$, L列 $4 \sim 7, \mathrm{~K}$ 列 7 ) であり, 右背 下部, 左背部および右胸部下方へ行くに従い $Q_{30}$ の 出現率が減少した。一方，左胸部を中心にした領 域にはQ $Q_{30}$ は全くみられなかつた。

\section{疾患群における $\mathbf{Q}_{\mathbf{3 0}}$ 出現率の体表面分布}

図 4 は前壁収縮異常群の56才男性例で, 左前下 行枝に高度狭窄があり，左室前壁和よび心室中隔 のakinesisを認めた。 $Q_{30}$ は右胸部，胸部中央上部 および背部のほとんどの領域に認められた，疾患 群全体を推計学的にみると（図 5)，対照群に比べ

\begin{tabular}{|c|c|c|c|c|c|c|c|c|c|c|c|c|c|}
\hline & & {$[2$} & 26.3 & 12.3 & 8.8 & 7.0 & 5.3 & 3 & & & 93.0 & 94.7 & \\
\hline & & 14.0 & 7.0 & 1.8 & 1.8 & 0.0 & \begin{tabular}{|l|}
0.0 \\
\end{tabular} & 0.0 & & 24.6 & & & \\
\hline & 5.61 & 17.5 & 8.8 & 1.8 & 0. & 0.0 & 0.0 & 0.0 & 0.0 & 0.0 & & & \\
\hline & 50.9 & 19.3 & 10.5 & 5.3 & 0.0 & 0.0 & \begin{tabular}{|l|}
0.0 \\
\end{tabular} & 0.0 & 0. & 0.0 & & & \\
\hline & 35.11 & 17.5 & 8.8 & 1.8 & 0 & 0.0 & 0.0 & 0. & 0.0 & 0.0 & & & \\
\hline & 14.0 & 14.0 & 5.3 & 0.0 & 0.0 & 0.0 & 0.0 & 0.0 & 0.0 & 0.0 & & & \\
\hline & 10.5 & 7.0 & \begin{tabular}{l|l}
3.5 \\
\end{tabular} & 0.0 & 0.0 & 0.0 & \begin{tabular}{|l|}
0.0 \\
\end{tabular} & \begin{tabular}{|l|}
0.0 \\
\end{tabular} & 0.0 & $\overline{0.0}$ & & 3 & \\
\hline
\end{tabular}

因 3，対照群における $\mathrm{Q}_{30}$ の体表面出現率分布 因は健常男子57名に拈けるQ $\mathrm{Q}_{30}$ (幅 $30 \mathrm{msec}$ 以上Q 波）の出現率（\%）を示す，右背部上方を中心にQ 高頻度で出現し，左前および左側胸部を中心にQ $Q_{30} か ゙$ 出 現しない領域が厸がる。

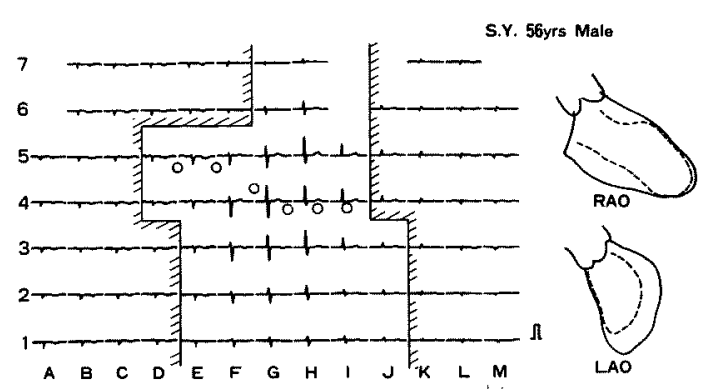

図 4, 前壁収縮異常群の 1 例

斜線で囲つた領域はQ つの白丸は標準胸部誘導点を示す。左前下行枝近位部 に高度 $(90 \%)$ 狭窄があり，左室前壁㧍よび中隔は akinesisを呈する. 右胸部, 胸部中央上部および背部の 大部分に $Q_{30}$ が出現している、V1のr波は小さいが，標 準12誘導心電图に病的Q波乱よびpoor $\mathrm{r}$ wave progressionは出現していない。

$\tau V 1 \cdot V 2$ 誘導点の上方の胸部中央上方部, 左鎖骨 下部および右胸部で $Q_{30}$ の出現率が有意に高かつ た. 特に, 胸部中央上方部 $(\mathrm{D}$ 列 $6 \cdot 7, \mathrm{E}$ 列 $6 \cdot 7$, F列 7$)$ ，左鎖骨下部 (G列 7, H列 7$)$ 括よび鎖骨 中線付近右胸部 (B列 $4 \cdot 6, \mathrm{C}$ 列 $2 \cdot 4 \cdot 6 \cdot 7$ ) で はQ $\mathrm{Q}_{30}$ の出現率が $16.7 \%$ から56.3\%であり,対照群 との出現率差が顕著であつた（ $\mathrm{p}<0.01 ）$ 。これら の領域に和ける $\mathrm{Q}_{\mathbf{3 0}}$ の前壁収縮異常に対する陽性 予測率（図 6) は63.4\%から92.3\%であつた。

収縮異常の程度别によるQ ${ }_{30}$ の出現率の検討(図) 7）では，疾患群全体と同様に軽度収縮異常群， 


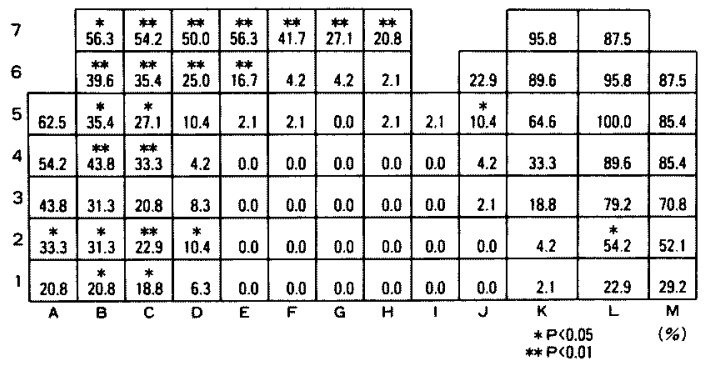

図 5，前壁收縮異常群における $\mathrm{Q}_{30}$ の体表面出現率分 布

図は前壁収縮異常群48名のQ $\mathrm{Q}_{30}$ の出現率分布を示す。 星印はQ $\mathrm{Q}_{30}$ の出現率が対照群のそれに比べて有意に高 い領域を示す。胸部上方括よび右胸部で $Q_{30}$ の出現率が 有意に増加している。

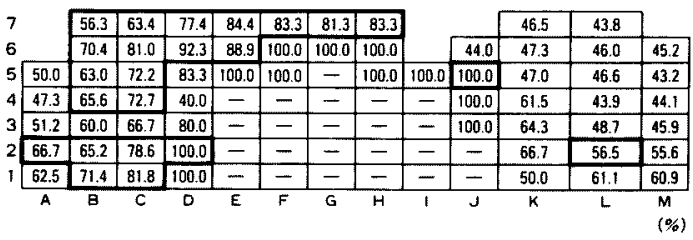

図6.前壁収縮異常群に括ける $\mathrm{Q}_{30}$ の陽性予測率 図は前壁収縮異常群48名における 対する陽性予測率を示す.太枠は $Q_{30}$ の出現率が対照群 に比べ有意に増加していた領域（図 5 参照）を示す. この領域に拈いて胸部上方拉よび右胸部で陽性予測率 が高值を示した。

高度収縮異常群ともに対照群に比べて右胸部およ びV1・V2誘導点の上方領域で $\mathrm{Q}_{30}$ の出現率が有意 に高かつた。高度収縮異常群と軽度収縮異常群と を比較すると(図 7 ), 高度収縮異常群では前記と ほぼ同様の領域で $Q_{30}$ の出現率が高い傾向を示し， その中で, $\mathrm{C} 1 \cdot \mathrm{D} 3 \cdot \mathrm{E} 6$ では $\mathrm{Q}_{30}$ の出現率に $\mathrm{p}<0.05$ の有意差が存在した。な拈，心筋梗塞群は狭心症 群と比べ, ほぼ前記と同様の領域で $\mathrm{Q}_{30}$ の出現率が 高い傾向を示したが, その差は有意ではなかつた。

標準心電図誘導点以外の領域における誘導点の 組合せによる左室前壁収縮異常の推定

感度 $15 \%$ 以上から陽性予測率 $85 \%$ 以上を示した 誘導点はV1・V2誘導点の上部に位置するD6およ びE6の 2 点であつた.これらの5ち少なくともい ずれか 1 点にQ $\mathrm{Q}_{30}$ が存在すれば" $\mathrm{Q}_{30}$ 陽性”とした場 合の感度は $27.1 \%$, 陽性予測率 $92.9 \%$, 診断精度

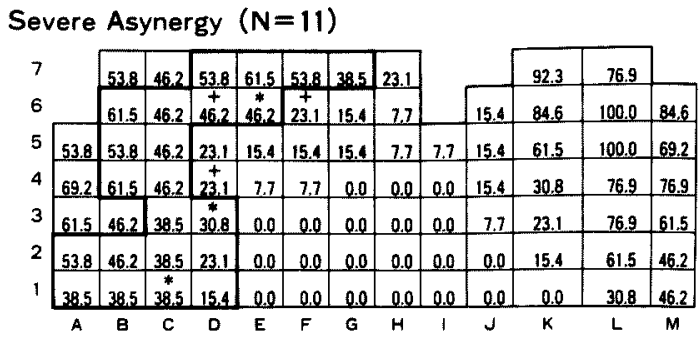

Mild Asynergy $(\mathrm{N}=37)$

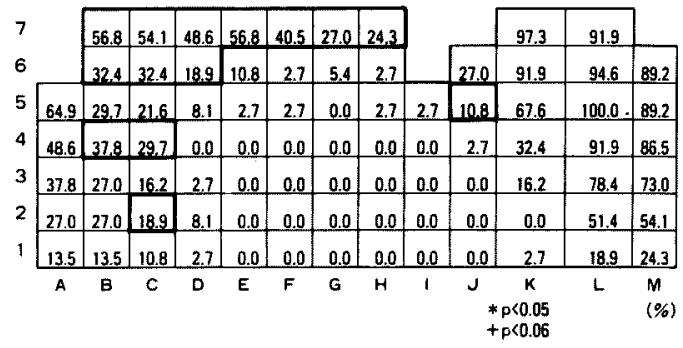

図 7. 前壁収樎異常の程度別にみた $\mathrm{Q}_{30}$ の出現頻度 akinesis, dyskinesis执よびaneurysmを高度収樎異 常（Severe Asynergy）とし, hypokinesisを軽度収縮 異常（Mild Asynergy）とした. 上段は高度収綟異常 群11例の, 下段は軽度収縮異常群37例のQ $Q_{30}$ の出現頻度 を示す、太わくは対照群に比べて $Q_{30}$ の出現頻度が有意 に $(\mathrm{p}<0.05)$ 增加した領域を示す，また，高度収縮異 常群につけた*および十で示す有意差検定は高度収縮 異常群之軽度収縮異常群間に和ける $Q_{30}$ の出現率の比 較である. 中央寄り右胸部拉よび胸部中央上方で高度 収縮異常群のQ $\mathbf{Q}_{30}$ の出現率が軽度収縮異常群のそれと 比べて有意に高い.

は65.7\%であつた。これらの誘導点の右方で陽性 予測率は $81.0 \%$ とやや低下寸るが，感度が $35.4 \%$ と高かつたC6を加亲て, C6・D6・E6の 3 点のうち 少なくとも 1 点に $\mathrm{Q}_{30}$ が存在すれば“ $\mathrm{Q}_{30}$ 陽性”とし た場合には，上記の值が括の括の，35.4\%, $81.0 \%$ および66.7\%であつた. C6の替わりに感度が高く かつ陽性予測率が $70 \%$ 以であつた右胸部中央の $\mathrm{C} 4$ 加えたC4・D6・E6の 3 誘導点を選んだ場合は 上記の值がおのおの $37.5 \% ， 75.0 \%$ おび $65.7 \%$ であつた，さらにC4・C6・D6・E6の 4 誘導点を選 んだ場合について検討すると上記の值はおのおの $41.7 \% ， 74.1 \%$ および66.7\%であつた。

な拝，電気軸異常偏位例は対象から除外したた め, 疾患群の前額面QRS平均電気軸は, -14 度か 
ら+90度の範囲にあり，その平均は $44.8 \pm 25.9$ 度 （平均士標準偏差）であつた。

\section{考 案}

標準誘導心電図上の異常Q波は心筋梗塞の診断 に有用であるが，血清酵素検査にて，あるいは病 理学的に確認された心筋梗塞または心筋線維化㾝 痕の診断に対して19３9\%の偽陰性率を示すとい われている(10) 13). 一方，標準12誘導心電図異常 $\mathrm{Q}$ 波の左室壁収縮異常に対する感度は44 87\% と報

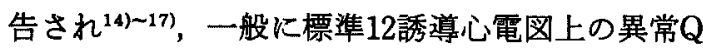
波は左室壁収縮異常に対する感度が低いとされて いる ${ }^{18)}$ 本研究では前壁収縮異常例の $67 \%$ が標準 誘導心電㘡でその判定が可能であり，上記の報告 と一致した.

\section{$\mathrm{V} 1$ V6誘導点以外の領域における $\mathbf{Q}_{30}$ による 左室前壁収縮異常の推定}

$\mathrm{V} 1 \cdot \mathrm{V} 2$ 誘導点の上方領域を含めた胸部中央上 部および右胸部領域における 異常に対する感度は十分高くはなかつたが, 対照 群におけるこれらの領域でのQ $\mathbf{Q}_{30}$ 出現率は非常に 低く，このため陽性予測率は高值を示した。この 結果は標準12誘導心電図に異常Q波が存在しなく てむ,これらの領域にQ $\mathbf{Q}_{\mathbf{3 0}}$ が認められれば左室前壁 の収縮異常が存在する可能性が高いことを示す。 なお，本研究の対照群に扣けるV1・V2誘導点の上 方領域で $Q_{30}$ の出現率が低かつたのはPrinzmetal

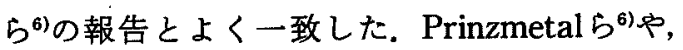
Wenら7は心蔵カテーテル検査などによる稁付け および推計学的検討を行なつてはいないが，標準 誘導心電図で診断できず胸骨上部領域の異常 $\mathrm{Q}$ 波 により診断できた急性前壁梗塞例を報告し，胸骨 上部の領域に括ける異常Q波の重要性を強調して おり，我々の結果とよく一致した。

本研究では, 疾患群で右胸部就よび胸部中央上 部にQ $Q_{30}$ が出現した理由は明らかではないが,いく つかの説明が可能である.すなわち, 対照群にお いてもこれらの領域ではr波はかなり小さく，心筋 梗塞，または心筋虚血によるQRS初期のわずかな 起電力の減弱がこれらの領域でのr波の消失を招 き， $\mathrm{Q}_{30}$ を形成する可能性が考えられる.我々は標
準12誘導心電図に梗塞所見の認められた例も含め た前壁収縮異常群全体ではV1〜V3誘導点を含 め,その上方領域で $Q_{30}$ の感度および診断精度が最 も高いという結果を得ている19). 本研究では標準 12誘導心電図に異常Q波，またはpoor $r$ wave progressionが存在した症例は予め対象から除外 したため, V1〜V3誘導点領域には $\mathrm{Q}_{30}$ がなく, 胸 部中央上部に $\mathrm{Q}_{30} か ゙$ 存在する症例が対象として残 されたものと考えられる. Selvester ら20) simulation studyの結果, 左室前壁の一部の起電 力は胸部中央上部に，中隔に近い前壁および中隔 の起電力は右胸部におのおの反映されるとしてお り，右胸部拉よびV1-V2の上方に $\mathrm{Q}_{30}$ が出現した 我々の結果に符合寸る.な拉, 右胸部下方でも $Q_{30}$ の出現率が対照群と比べて高い領域が見られた が,この理由は不明である.

QRS平均電気軸の偏位が生じると正常では出 現しない領域に異常Q波が出現することがありう る. 本研究では異常軸偏位例は対象から除外して おり, 疾患群のQRS平均電気軸は対照群のそれと 差がなく，得られた所見は軸偏位によるものとは 考えられない。

なお，本研究では胸部全体において， $\mathrm{Q}_{30}$ の左室 前壁収縮異常に対する感度は高くなかつたため診 断精度もあまり高くはならなかつた。これは標準 12誘導心電図で異常 $\mathrm{Q}$ 波を認めた例は，対象から 除外した結果と考えられる。

\section{収縮異常の程度と $\mathbf{Q}_{\mathbf{3 0}}$ 出現率との関係}

高度収縮異常群, 軽度収縮異常群共に対照群之 比べて $\mathrm{Q}_{30}$ の出現率がV1・V2誘導点の上方および 右胸部の一部で有意に増加していた，さらに，高 度收縮異常群は軽度収縮異常群に比べて上記とほ ぼ同様の領域で $\mathrm{Q}_{30}$ の出現率が高い傾向を示した が，このことは心筋線維化の程度の違いを反映し ていると考えられた。

心筋梗塞群では狭心症群に比べ, $\mathrm{Q}_{30}$ の出現率が 上記とほぼ同じ領域で高い傾向を示したものの， 有意差ではなかつたが，この結果は両者間に高度 収縮異常群と軽度収樎異常群の占める割合に差が なかつたことによると考えられる。 


\section{標準誘導以外の少数の誘導の組み合わせによる 診断率}

日常臨床上，非常に多数の誘導の心電図を記録 することは容易ではないので，できるだけ少ない 誘導数で，かつ診断に有用な誘導点を見い出すこ とがのぞまれる。今回の検討ではV1・V2誘導点の 上方に位置するD $6 \cdot \mathrm{E} 6$ の 2 誘導点，またはそれに 右胸部のC6を加点た 3 誘導点を用いると，標準 12 誘導心電図で診断できなかつた前壁収樎異常例の おのおの $27 \%$ 扎よび35\%が検出でき，かつその陽 性予測率が93\%括よび81\%と高かつた。この結果 から，前壁収縮異常の心電図診断に際し，これら の誘導のQ $Q_{30}$ を観察することが有用と考えられた. さらに右胸部中央のC4を加えた 4 誘導を用いる と感度は $41 \%$ に上昇したが，陽性予測率は64\%に 低下し，有用性はむしろ低下した。これらの結果 からV1－V2の上方領域および右胸部の $2 ， 3$ の誘 導を標準誘導心電図に加省ることは，冠動脈病変 による前壁収縮異常の見落としを防ぐために極め て有用と考えられた。

標準12誘導心電図上の異常Q波が一般に左室壁 収樎異常を過少評価する理由として，相対する左 室壁, 例觉ば前壁と後壁両者の梗塞による起電力 欠損による電気的効果の相殺 ${ }^{11)}$, 線維化巣と正常 心筋の混在 ${ }^{12)}$, 梗塞の大きさが小さいこと ${ }^{13)}$ が指摘されている.さらに，標準12誘導心電図の 異常Q波は，心外膜電位mappingに抢けるQ波より も左室壁収縮異常の反映度が低いことが報告され ており ${ }^{18)}$, 標準 12 誘導心電図は誘導点数が少ない こと，および心電図誘導点と心臟との相対的な位 置関係が個々の症例で異なることも，標準12誘導 心電図異常Q波の感度が十分でない理由と考えら れる. 本研究では起電力欠損による電気的効果の 相殺による影響を除くため，対象を前壁以外の領 域には収縮異常を認めない症例のみに限定した。

本研究に打いて標準12誘導心電図に病的Q波お よびpoor $\mathrm{r}$ wave progressionを示す例は除外し たが，ST-Tの異常のみを示す例は心筋梗塞の確 定診断が困難なため8, また，IまたはaVLのどち らか一方にのみ病的Q波を示す例は正常でもあり
らるとされているため8対象に含めた。

本研究に括ける左室収樎状態の評価は 2 方向の 左室造影によつたこと，および造影剤を高圧力で 注入するため，笅密には左室の収縮異常の観察に 完全なものではない。したがつて，左室造影に比 べて解像力は劣るが，より自然な収縮状態を反映 すると考えられる超音波検查，あるいは心筋血流 分布を反映するアイントープ検查法等と $\mathrm{Q}_{30}$ の出 現率の対比が今後望まれる。また胸郭の形状およ び誘導点と心臓との位置関係により, 各誘導点の $\mathrm{Q}_{30}$ の出現率が変化する可能性があり, 本研究にお いては肺気重および胸郭形成術施行者は除外した が,レントゲンCT検查等に基づいた，誘導点と心 臓との位置関係による $\mathrm{Q}_{30}$ の分布の差異に対する 検討も今後必要と考学られる。

\section{結 論}

左室造影上, 前壁にのみ収縮異常を呈するが, 標準12誘導心電図に異常Q波括よびpoor $\mathbf{r}$ wave progressionを認めない冠動脈疾患患者48名（疾患 群)における体表面上の $\mathrm{Q}_{30}(\geqq 30 \mathrm{msec})$ の出現率 を健常対照群57名のそれと比較した.

疾患群では, V1・V2誘導点の上方領域および右 胸部で $\mathrm{Q}_{30}$ の出現率が対照群に比べて有意に高か つた.その感度は $17 \%$ \%6\%と高くはなかつたが， 対照群ではこれらの領域にはQ $\mathrm{Q}_{30}$ は任とんど出現 しないため, 陽性予測率は63\% 92\%と高かつた。

高度收縮異常群は軽度収縮異常群に比べて, 上 記と同様の領域でQ $\mathbf{Q}_{\mathbf{3 0}}$ の出現率が高かつた.

$\mathrm{V} 1$ - V2誘導点の上方領域および右胸部領域の 2 ないし 3 誘導の組合わせにより，標準12誘導心

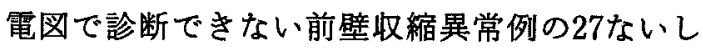
35\%が新たに診断でき，かつその陽性予測率が93 ないし81\%と高かつた。

これらの成績から体表面電位図は標準12誘導心 電図で診断の困難な左室前壁収縮異常の診断に有 用であつた。 また，これらの結果から，V1・V2誘 導点の上方領域および右胸部領域における 2 ない し 3 個の誘導を標準12誘導心電図に加えることは 冠動脈病変による左室前壁収縮異常の心電図診断 の向上に有用と考えられた。 
謝辞 本研究に御劦力いただいた三菱重工名古屋病院 市江良康先生および県西部浜松医療センター 平山治雄先 生に深謝します。

\section{文献}

1) Williams RA, et al: Electrocardiographic, arteriographic and ventriculographic correlations in transmural myocardial infarction. Amer J Cardiol 31:595, 1973.

2) Miller RR, et al: Electrocardiographic and cineangiographic correlations in assessment of the location, nature and extent of abnormal left ventricular segmental contraction in coronary artery disease. Circulation $49: 447,1974$.

3) Yamada $\mathrm{K}$, et al: Body surface isopotential maps: Clinical application to the diagnosis of myocardial infarction. Jpn Heart J $19: 28,1978$.

4) Hayashi $\mathrm{H}$, et al: Diagnostic value of body surface map in myocardial infarction: Assessment of location, size and ejection fraction as compared with coronary cineangiography and $201 \mathrm{~T} 1$ myocardial scintigraphy. Jpn Circ J 44 : $197,1980$.

5) Zema MJ, et al: Electrocardiographic poor $r$ wave progression. II. Correlation with angiography. J Electrocardiology 12(1) : 11, 1979.

6) Printzmetal $M$, et al: High anterior myocardial infarction: XX. Studies on the mechanism of ventricular activity. Circulation 15: 575, 1957.

7) Wen Y, et al: Multiple precordial leads QRS mapping and its clinical application: A preliminary report. Chinese Med J 94 : 755, 1981.

8) Littmann $\mathrm{D}$ : Textbook of electrocardiography. Harper and Row, New York, 1972, p277.

9) Toyama J, et al: Microcomputer processing system for body surface isopotential map. Proceedings of Computers in Cardiology, 191, Wiliamsburg, 1980.

10) Horan LG, et al : Significance of the diagnos- tic $Q$ wave of myocardial infarction. Circulation $43: 428,1971$.

11) Abbott JA, et al: Nondiagnostic electrocardiogram in patients with acute myocardial infarction. Amer J Med 55 : 608, 1973.

12) Burch GE, et al : A correlative study of postmortem, electrocardiographic, and spatial vectorcardiographic data in myocardial infarction. Circulation $18: 325,1958$.

13) Roberts WC: The coronary arteries and left ventricle in clinically isolated angina pectoris. A necropsy analysis. Circulation $54: 388,1976$.

14) Gottlieb RS, et al : Correlation of abnormal $Q$ waves, coronary pathology, and ventricular contractility. Amer Heart J 90 : 451, 1975.

15) Bodenheimer $M M$, et al: $Q$ waves and ventricular asynergy: Predictive value and hemodynamic significance of anatomic localization. Amer J Cardiol $35: 615,1975$.

16) Young E, et al: Vectorcardiographic diagnosis and electrocardiographic correlation in left ventricular asynergy due to coronary artery disease. Circulation 51:467, 1975.

17）鷹津文䵇，他：左室造影之心電図所見一虚血性心 疾患202例における検討。心䁍 9(4)：299，1977。

18) Bodenheimer MM, et al : Correlation of pathologic $Q$ waves on the standard electrocardiogram and epicardial electrogram of the human heart. Circulation $54: 213,1976$.

19) Kojima $H$, et al: Distribution of abnormal $Q$ waves on body surface in relation to left ventricular wall motion abnormalities in myocardial infarction. Texas Heart Institute J $10: 23,1983$.

20) Selvester RH and Gillespie TL: Simulated ECG surface map's sensitivity to local segments of myocardium. Adv Cardiol 10 Karger, Basal, 1974, p120. 